\title{
PERANCANGAN ALAT PENGUKUR TINGGI BADAN DIGITAL DENGAN METODE SONAR
}

\author{
${ }^{1)}$ Roni Salambue, ${ }^{2)}$ Arby Winata \\ ${ }^{1)}$ Universitas Riau, ${ }^{2}$ Universitas Abdurrab \\ 1)Jl.HR Subantas KM.12.5, ${ }^{2}$ Jl. Riau Ujung no.73 Pekanbaru \\ E-Mail: roni.salambue@gmail.com,arby.winata@yahoo.com
}

\begin{abstract}
ABSTRAK
Sonar adalah singkatan dari (sound of ranging) yang berarti teknik penyebaran bunyi untuk navigasi dan berkomunikasi atau mendeteksi kapal-kapal lain. Sonar dapat diterapkan untuk mengukur jarak suatu objek dengan cara memantulkan gelombang ultrasonik ke objek dan kemudian ditangkap melalui reciver. Gelombang ultrasonik tersebut dipantulkan oleh sensor SR04 dan menggunakan arduino uno sebagai mikrokontroler tempat pemrosesan perhitungan jaraknya. LCD digunakan untuk menampikan hasil pengukuran supaya lenih mudah dalam mengambil hasil ukuran tinggi badan. Arduino merupakan perangkat yang dapat diprogram dan dikoneksikan langsung dengan sebuah sensor ultrasonik yang digunakan untuk pengukuran. Sensor ultrasonic diletakkan diatas tiang setinggi $200 \mathrm{~cm}$, dan jarak 200 $\mathrm{cm}$ tersebut digunakan sebagai patokan pengukuran. Pengukuran menggunakan manual dan digital dapat berjalan dengan baik, tetapi menggunakan digital tingkat kecepatan pengukuran lebih baik dibandingpengukuran menggunakan manual.
\end{abstract}

Kata Kunci: arduino, pengukur tinggi badan digital, sonar, ultrasonik, mikrokontroler

\begin{abstract}
Sonar is an abbreviation of the (sound of ranging) which means techniques for distributing sound to navigate and communicate with or detect other vessels. Sonar can be applied to measure the distance of an object by reflecting the ultrasonic waves to the object and then captured via the reciver. The ultrasonic waves reflected by the sensor SR04 and use a microcontroller arduino uno as the distance calculation processing. LCD used to display the measurement results in order lenih easy in taking height measurement results. Arduino is a programmable device and be connected directly with an ultrasonic sensor that is used for the measurement. Ultrasonic sensors placed on the pole as high as $200 \mathrm{~cm}$, and a distance of $200 \mathrm{~cm}$ was used as a benchmark measurement. Measurements using a digital manual and can work well, but using a digital level measurement speed is better dibandingpengukuran using manual.
\end{abstract}

Keywords: arduino, digital height gauge, sonar, ultrasonic, microcontroller

\section{PENDAHULUAN}

Perkembangan teknologi begitu pesat sehingga hal- hal yang dilakukan secara manual dapat dilakukan dengan cara otomatis dan efisiesi waktu yang tepat. Namun masih ada hal-hal yang mudah memakan waktu kita yang sebenarnya bisa saja dilakukan dengan cepat jika ada sistem atau alat pendukungnya. Seperti pada saat kita membuat SIM dan paspor yang harus mengantri lama pada saat melakukan pengukuran tinggi badan yang masih menggunakan cara manual. Bahkan pada saat mendaftar pada universitasuniversitas tertentu masih menggunakan cara manual. Seperti hal nya penulis mengambil studi kasus di Universitas Abdurrab. Saat ini Universitas Abdurrab masih menggunakan metode pengukuran secara manual untuk proses penerimaan 
mahasiswa bidang studi kebidanan, akademi keperawatan dan prodi kesehatan lainnya, hal ini sebenarnya memakan waktu atau tenaga bagi para staff penerimaan mahasisiwa baru. Penulis berharap alat yang di rancang ini dapat membantu dalam memecahkan permasalahan tersebut.

\section{Permasalahan yang akan diteliti}

Pembahasan masalah dalam laporan penelitian ini mencakup pemecahan masalah pengukuran tinggi badan yang masih menggunakan cara manual di Universitas Abdurrab yang tidak efisien waktu dan tenaga serta cara kerja mikrokontroler arduino dan ultrasonik dan untuk mengimplementasikan mikrokontroler arduino dan sensor ultrasonik dalam perancangan alat pengukuran tinggi badan

\section{Rumusan Masalah}

Pembahasan masalah dalam laporan tugas akhir ini mencakup masalahmasalah sebagai berikut :

1. Bagaimana pemecahan masalah pengukuran tinggi badan yang masih menggunakan cara manual di Universitas Abdurrab yang tidak efisien waktu dan tenaga?

2. Bagaimana cara kerja mikrokontroler arduino dan ultrasonik?

3. Bagaimana mengimplementasikan mikrokontroler arduino dan sensor ultrasonik dalam perancangan alat pengukuran tinggi badan?

\section{Batasan Maslah}

Dikarenakan luasnya permasalahan dalam pembahasan dan agar tidak terjadi kesalah pahaman maksud dari apa yang ada di dalam penulisan tugas akhir maka dibutuhkannya pembatasan masalah tersebut antara lain :

1. Pengujian alat dilakukan pada orang yang berambut normal tidak kribo ataupun mengembang ke atas.

2. Pengujian alat dilakukan pada orang yang memiliki tinggi badan normal orang asia yaitu maksimal 2 meter.

3. Sensor ultrasonik hanya sebagai pengukur jarak dari objek terdekat.

\section{Tujuan Penelitian}

1. Perancangan alat ini dapat di implementasikan sebagai alat pengukur tinggi badan yang sah di Universitas Abdurrab pada saat penerimaan mahasiswa baru untuk prodi kesihatan.

2. Sebagai pengaplikasian ilmu pengetahuan yang diperoleh dari perkuliahan terhadap kehidupan sehari hari.

3. Merancang dan mengetahui cara kerja sensor ultrasonik denganpengendali Mikrokontroler Arduino

\section{Manfaat Penelitian}

1. Sebagai bahan pembelajaran dan pengembangan alat-alat atau rancanganrancangan menggunakan mikrokontroler yang saat ini sangat berkembang pesat.

2. Sebagai rujukan atau referensi bagi peneliti atau perancang yang akan melakukan penelitian dan perancangan berikutnya mengenai pengembangan mikrokontroler menggunakan sensor ultrasonik.

\section{Universitas Abdurrab}

Universitas Abdurrab adalah bermula dari chest clinic yang merupakan cikalbakal dari Rumah Sakit Prof. Tabrani pada tahun 1979. Selanjutnya berturutturut pada tahun 1996 dibuka Akademi 
Perawatan (AKPER), Akademi Analis Farmasi \& Makanan (AKAFARMA) tahun 1999, Akademi Fisloterapi (AKFIS) tahun 2002 dan Akademi Kebidanan (AKBID) tahun 2002 oleh Yayasan Abdurrab. Berdasarkan Surat Keputusan Menteri Pendidikan Nasional RI No. 75/D/O/2005 secara resmi berdirilah Universitas Abdurrab dengan program studi:

1. S1 Fisika

2. S1 Kimia

3. S1 Biologi

4. S1 Matematika

5. S1 Teknik Informatika

6. S1 Teknik Sipil

7. S1 Psikologi

8. S1 Ilmu Pemerintahan

9. S1 Ilmu Komunikasi

10. S1 Hubungan Internasional

11. DIII Keperawatan

12. DIII Kebidanan

13. DIII Fisioterapi dan

14. DIII Analis Farmasi dan Makanan.

Berdasarkan surat Dirjen Dikti

Depdiknas RI No. 2128/D/T/2tanggal 11 Juli

2008 secara resmi keluar ijin penyelenggaraan program studi S1 Pendidikan Dokter pada Universitas Abdurrab dan tanggal 11 Juli ditetapkan sebagai hari jadi Universitas Abdurrab. Universitas ini bernama Universitas Abdurrab dan disingkat Univrab yang berkedudukan di Jl. Riau Ujung No. 73 Tampan Pekanbaru 28292 Riau Indonesia Telp. (0761) 38762, 859839,7098153, 839036, Fax. (0761) 859839, 7098153 WEBSITE : www.univrab.ac.id EMAIL: info@univrab.ac.id.

\section{Sonar}

Sonar merupakan kependekan dari Sound Navigation and Ranging, bila diterjemahkan dalam bahasa Indonesia bisa berarti pengukuran jarak dan navigasi suara. Dengan kata lain, Sonar merupakan teknik yang digunakan untuk menentukan posisi (jarak) dan navigasi dengan menggunakan gelombang suara (akustik). Navigasi sendiri merupakan tata cara menjalankan pesawat ataupun kapal laut. Lebih spesifik lagi, teknik sonar dapat digunakan untuk mencari keberadaan suatu objek yang berada di dalam atau dasar laut. Pada peralatan sonar terdapat suatu alat yang memancarkan gelombang bunyi yang merambat dalam air, gelombang bunyi tersebut akan memantul kembali ketika mengenai suatu obyek. (Muis,2018:2).

\section{Mikrokontroler}

Mikrokontroler pertama kali dikenalkan oleh Texas Instrument dengan seri TMS 1000 pada tahun 1974 yang merupakan mikrokontroler 4 bit pertama. Mikrokontroler ini mulai dibuat sejak 1971 yang merupakan mikrokontroler dalam sebuah chip, lengkap dengan RAM dan ROM. Kemudian, pada tahun 1976 Intel mengeluarkan mikrokontroler yang kelak menjadi popular dengan nama 8748 yang merupakan mikrokontroler 8 bit, yang merupakan mikrokontroler dari keluarga MCS 48. Sekarang di pasaran banyak sekali ditemui mikrokontroler mulaidari 8 bit sampai dengan 64 bit, sehingga perberdaan antara mikrokontroler dengan mikroprosesor sangat tipis (Khadir, 2013: 2).

Mikrokontroler adalah sebuah sistem komputer fungsional dalam sebuah chip. Di dalamnya terkandung sebuah inti prosesor, memori (sejumlah kecil RAM, memori 
program atau keduanya), dan perlengkapan input-output. Mikrokontroler adalah salah satu dari bagian dasar dari suatu sistem komputer. Meskipun mempunyai bentuk yang jauh lebih kecil dari suatu komputer pribadi dan komputer mainframe, mikrokontroler dibangun dari elemen-elemen dasar yang sama. Secara sederhana, komputer akan menghasikan output spesifik berdasarkan inputan yang diterima dan program yang dikerjakan. (Syahwil, 2013: 53)

\section{METODE}

Kerangka kerja Perancangan Alat Pengukur Tinggi Badan melingkupi aktifitas - aktifitas sebagai berikut :

1. Tahap pertama dilakukan identifikasi masalah yang merupakan awal dari

penelitian penyusunan laporan tugas akhir ini. Masalah yang di

identifikasi adalah sebagai berikut:

a. Pengukuran yang masih menggunakan cara manual yang menyita waktu, dengan adanya ide rancangan ini diharapkan dapat memaksimalkan efisiensi waktu.

b. Kebutuhan sistem atau alat yang bisa membatu dalam masalah pengukuran tinggi badan.

2. Tahapan kedua yang dilakukan adalah melakukan studi pustaka atau pengumpulan dasar teori yang berkaitan dengan alat yang akan dibuat. Hal ini dilakukan untuk memudahkan teknik perencanaan rangkaianpenentuan nilainilai komponen dan pemahaman karakteristik komponenyang dipakai.

3. Tahapan ketiga yaitu melakukan perancangan desain rangkaian beserta nilai-nilai komponen yang terpasang berdasarkan hasil perhitungan yang didapat.

4. Tahapan keempat yaitu melakukan pengumpulan komponen-komponen yang akan dipakai dalam penyusunan rangkaian yang telah ditentukan berdasarkan hasil perancangan.

5. Tahap keenam yaitu pemasangan rangkaian komponen-komponen menjadi satu rangkaian alat pengukur tinggi badan digital.

6. Tahap kelima yaitu melakukan uji coba rangkaian pada masing-masing blok rangkaian modul sensor ultrasonik $\mathrm{HC}$ SRF04, rangkaian mikrokontroler arduino uno, LCD (Liquid Crystal Display) dan rangkaian indikator alarm buzzer. Dengan memberikan catu daya DC pada rangkaian, maka dapat diketahui operasi kerja yang dihasilkan oleh masing-masing blok rangkaian. Apabila pada rangkaian ada yang mengalami permasalahan, maka dilakukan analisa kerusakan, kesalahan penggunaan atau pemasangan komponen dan jika memungkinkanrangkaian dapat dimodifikasi atau memperbaiki perancangan rangkaian. Apabila rangkaian sudah bekerja sesuai dengan harapan maka dilakukan tahap berikutnya.

7. Tahap ketujuh yaitu melakukan uji rangkaian keseluruhan (hardware) dan uji prangkat lunak (software). Apabila operasi kerja rangkaian mengalami permasalahan, maka dilakukan analisa kerusakan, kesalahan penggunaan atau pemasangan komponen dan jika memungkinkan rangkaian dapat dimodifikasi atau memperbaiki perancangan rangkaian. Begitu juga dengan uji perangkat lunak apabila 
mengalami kesalahan dalam pemograman akan dilakukan analisa dan modifikasi.

8. Pada tahap kedelapan ini adalah tahap terakhir setelah dilakukan uji coba keselurahan rangkaian yaitu tahap implementasi

\section{HASIL}

1. Analisa Pengukuran Tinggi Badan

Pada saat penerimaan mahasiswa baru untuk prodi kesehatan di universitas abdurrab khusus prodi kesehatan diwajibkan untuk melakukan pengukuran tinggi badan, namun pengukuran tersebut masih menggunakan cara manual, seperti menurunkan siku-siku pada tiang pengukuran itupun harus dibantu dengan staff atau karyawan untuk mendapatkan hasil pengukurannya.

2. Analisa Cara Kerja Sonar

Sonar adalah singkatan dari (sound navigation and ranging) yang berarti suatu teknik penyebaran bunyi untuk navigasi dan berkomunikasi atau mendeteksi kapal-kapal lain. Namun disini penulis menggunakan metode yang sama untuk mengukur jarak suatu objek dengan cara memantulkan gelombang ultrasonik ke objek dan kemudian ditangkap melalui reciver. Dengan menggunakan sensor SR04 yang dapat memantulkan dan menangkap kembali gelombang ultrasonic tersebut.

Berikut ini adalah cara kerja bagaimana sensor SR04 mendeteksi jarak suatu benda.

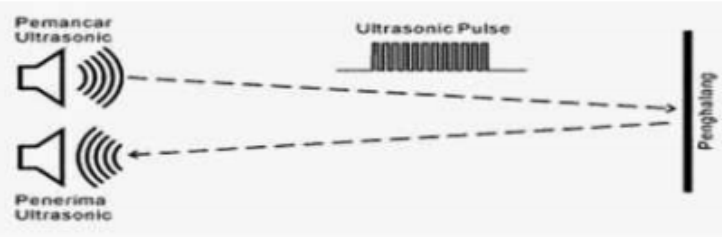

Gambar 1. Cara kerja sensor
3. Proses Pengukuran

Berikut ini adalah gambar penerapan metode sonar untuk pengukuran tinggi badan digital dengan menggunakan sensor ultrasonik SR04.

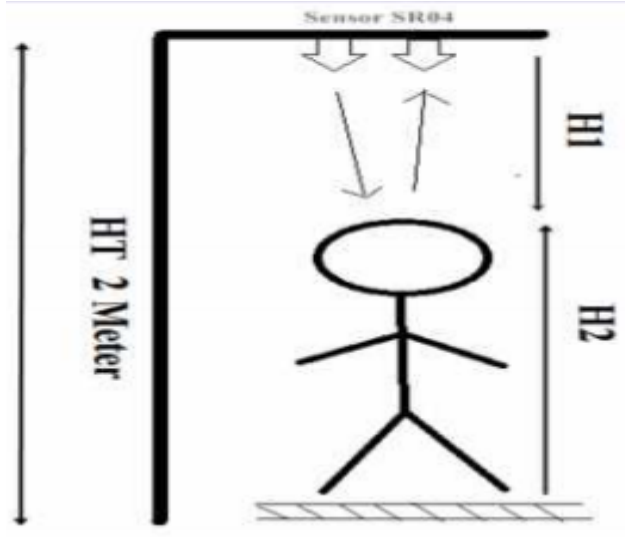

Gambar 2. Penerapan sensor ultrasonik SR04

Untuk penerapan metode sonar pada pengukuran tinggi badan digital ini tidak hanya sensor ultrasonik yang digunakan namun ada komponen lain yang sangat penting yaitu mikrokontroler sebagai tempat pemrosesan dan perhitungan dari gelombang yang dipantulkan. Proses pengukuran tinggi badan dilakukan ketika ada objek yang menutupi sensor ultrasonik tersebut dengan jarak yang sudah di atur setinggi 2 meter (HT) sebagai acuan kemudian sensor akan membaca jarak objek terdekat (H1/58) dan di kurang (HT) untuk mendapatkan tinggi badan yang di ukur (H2).

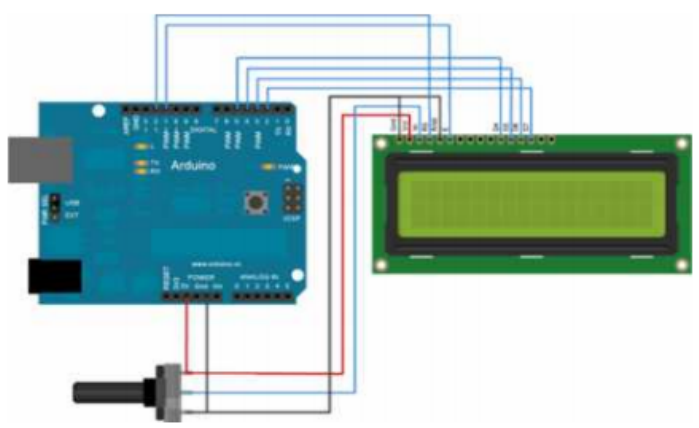

Gambar 3. Rangkaian Arduino dengan LCD 


\section{KESIMPULAN}

Dari keseluruhan proses pembuatan rancangan alat ukur tinggi badan dapat disimpulkan :

1. Perancangan alat pengukur tinggi badan digital ini diharapkan dapat di implementasikan pada penerimaan mahasiswa baru di Universitas Abdurrab untuk prodi kesehatan.

2. Mikrokotroler arduino sebagai pengendali utama untuk pemrosesan data jarak, sedangkan sensor ultrasonik berfungsi sebagai pengukur jarak dengan kecepatan rambatan suara 343,5 $\mathrm{cm} /$ detik yang hail pengukurannya lebih cepat.

3. Hasil pengukuran tinggi badan di tampilkan dalam satuan sentimeter pada LCD. Led dan buzzer berfungsi sebagai indikator ketika adanya pengukuran

\section{DAFTAR PUSTAKA}

[1] Arif, MU. Pengujian Sensor Ultrasonik Ping untuk pengukuran level ketinggian dan Volume Air.Jurnal Ilmiah "Elektrikal Enjiniring" UNHAS 2011; 9: 6-2.

[2] Chistianto,R. Cara Kerja Sensor Ultrasonik. 2015 : http://www.rizrobot.com. diakses tanggal 15/14/2015. Devantech. data sheet sensor ultrasonik .2009 : http://digi-bytes.com . diakses tanggal 15/04/2015.

[3] Khadir, Abdul. Dasar Pemograman Mikrokontroller Arduino.Jakarta:PT ELEX MEDIA KOMPUTINDO,2013.23.
[4] Muis,Saludin. Prinsip \& Aplikasi Sonar Sebuah Pengantar Praktis.Yogyakarta : GRAHA ILMU, 2008.2-3.

[5] Nurcahyo,Sidik. Aplikasi dan Teknik Pemograman Mikrokontroller Avr Atmel,Jakarta : PT ELEX MEDIA KOMPUTINDO, 2013.162-165.

[6] Oktavian I, Martinus, Sugianto. Pembuatan Sistem Otomasi Dispenser Menggunaan Mikrokontroler Arduino Mega 2560. Jurnal Fema 2013; 1:7-3.

[7] Sasongko,Bagus,Hari. Pemograman Mikrokontroler dengan Bahasa C. Yogyakarta: C.V ANDI OFFSET, 2012. 2-4.

[8] Syahwil,Muhammad, Panduan Mudah Simulasi \& Praktek Mikrokontroler

[9] Arduino, Yogyakarta: C.V ANDI OFFSET, 2012. 60-63.

[10] Yusuf,Muhammad. Prototipe Sensor Parkir Mobil Berbasis Mikrokontroler AT89S51.Jurnal Fema 2009 ;1: 28-34.

[11] Saptaji, H, W. Mudah Belajar Dengan Arduino Uno, Bandung: Penerbit Widya Media,2015. 167. 